\title{
Reproduction of the sea urchin Loxechinus albus across a bathymetric gradient in the Chilean Inland Sea
}

\author{
Reproducción del erizo Loxechinus albus en un gradiente batimétrico en el mar interior chileno
}

\author{
Carlos Molinet ${ }^{1,2}$, Carlos A. Moreno ${ }^{3}$, Edwin J. Niklitschek ${ }^{4}$, Manira Matamala ${ }^{5}$, \\ Mónica Neculman ${ }^{4}$, Alejandra Arévalo ${ }^{3}$, José Codjambassis ${ }^{1}$, \\ Patricio Diaz ${ }^{1}$ and Manuel Diaz ${ }^{1}$
}

\author{
${ }^{1}$ Programa de Investigación Pesquera, Instituto de Acuicultura, Universidad Austral de Chile, Los Pinos S/N balneario \\ Pelluco, Puerto Montt, Chile. cmolinet@uach.cl \\ ${ }^{2}$ Centro Trapananda, Universidad Austral de Chile, Portales 73, Coyhaique, Chile \\ ${ }^{3}$ Instituto de Ciencias Ambientales y Evolutivas, Universidad Austral de Chile, Campus Isla Teja, Valdivia, Chile \\ ${ }^{4}$ Centro I mar, Universidad de Los Lagos, Camino a Chinquihue Km. 6, Puerto Montt, Chile \\ ${ }^{5}$ Consultora Pupelde, Regimiento 1312, Puerto Montt, Chile
}

\begin{abstract}
Resumen.- La distribución batimétrica reportada para erizos de interés comercial va desde el intermareal hasta cientos de metros, aunque estudios reportados a profundidades mayores que $25 \mathrm{~m}$ son escasos. Se espera que erizos que habitan sitios someros tengan acceso a más alimento y desplegar un mayor desarrollo gonádico que aquellos erizos de hábitat más profundos. Los erizos en hábitat profundo pueden jugar un rol importante para mejorar la resiliencia de las poblaciones explotadas ubicadas en hábitat someros. El objetivo de este estudio fue verificar la existencia de parches del erizo Loxechinus albus reproductivamente activos en un gradiente batimétrico desde 0 a $100 \mathrm{~m}$ de profundidad en dos áreas de pesca del mar interior chileno. Para esto se evaluó el índice gonádico (IG) y el desove inducido con $\mathrm{KCl}$ en ejemplares adultos de $L$. albus recolectados entre la superficie y los $100 \mathrm{~m}$ de profundidad entre septiembre de 2008 y marzo de 2009. Los erizos fueron relativamente abundantes hasta $15 \mathrm{~m}$ de profundidad, escasos hasta $60 \mathrm{~m}$ de profundidad y sólo un parche de erizos fue encontrado entre 60 y 100 $\mathrm{m}$ de profundidad. Se observó una asincronía en el IG y el desove inducido entre estratos y áreas de muestreo, lo que sugiere que los erizos ubicados entre 30 y $100 \mathrm{~m}$ podrían estar reproductivamente activos y desovar en distintos periodos, aunque se desconoce su potencial aporte en la dinámica poblacional de L. albus. Futuros estudios deberían enfocarse en estudiar el rol de las escasas agregaciones profundas de L. albus sobre la dinámica de la población de este recurso, particularmente en áreas donde la presión de pesca es intensa.
\end{abstract}

Palabras clave: Parches profundos, capacidad reproductiva, desove inducido

Abstract.- The reported bathymetric distribution of commercial sea urchin species varies globally from the intertidal zone down to a depth of a hundred meters or more, although few studies have been conducted at depths $>25 \mathrm{~m}$. Urchins that inhabit shallow sites are expected to have access to more food and to display greater gonad development than those from deeper habitats. The latter could, however, play an important reproductive role by enhancing the resilience of the exploited populations. The objective of this study was to verify the existence of deep reproductively active patches of the edible sea urchin Loxechinus albus in two fishing areas of the Chilean Inland Sea, and compare the main reproductive features of these patches over the 0-100 m bathymetric gradients. We evaluated the gonadic index (GI) and $\mathrm{KCl}$-induced spawning in adult L. albus collected between the surface and $100 \mathrm{~m}$ depth between September 2008 and March 2009. Urchins were relatively abundant up to $15 \mathrm{~m}$ depth, few to $60 \mathrm{~m}$ depth and only one patch of urchins was found between 60 and $100 \mathrm{~m}$ depth. Asynchrony was observed in the GI and induced spawning between strata and sampling areas, suggesting that urchins located between 30 and $100 \mathrm{~m}$ may be reproductively active and may asynchronously spawn during the breeding season, although their potential contribution to the population dynamic is unknown. Future studies should examine the role of the scarce deep-water aggregations for the regional population dynamics of $L$. albus, in particular in areas where shallow populations have been heavily fished.

Key words: Deep patches, reproductive capacity, induced spawn 


\section{INTRODUCTION}

Sea urchins Loxechinus albus (Molina, 1782) are among the key benthic herbivores in Chilean coastal waters (e.g., Vásquez et al. 1984, Guisado \& Castilla 1987, Moreno \& Vega 1988, Vásquez 2001, Kino \& Agatsuma 2007, Pérez et al. 2010), and sustain the largest sea urchin fishery in the world (Andrew et al. 2002, Moreno et al. 2006, Moreno et al. 2011). The geographic distribution of $L$. albus runs from northern Peru $\left(6^{\circ} \mathrm{S}\right)$ to Tierra del Fuego $\left(55^{\circ} \mathrm{S}\right)$ and its bathymetric range extends from the shoreline to a depth of several hundred meters (Larraín 1975). The highest abundances and the commercial fisheries for this and other related species, in Chile as elsewhere, are limited to the first 20 to $30 \mathrm{~m}$ of the depth range (Inostroza et al. 1983, Keats et al. 1984, Vásquez et al. 1984, Gage \& Tyler 1985, Lawrence 2001, Basch \& Tegner 2007, Moreno et al. 2011).

Sea urchin preference for shallower habitats seems to be related to its herbivorous diet, which is heavily dependent upon kelp and other seaweed species (Vásquez et al. 1984, Agatsuma et al. 2000, Lawrence 2001, Vásquez 2001, Villouta et al. 2001, Burdett-Coutts \& Metaxas 2004, Senaratna et al. 2005, Shpigel et al. 2005, Vanderklift \& Kendrick 2005). Thus, higher food consumption, growth rates, early maturation schedules and higher reproductive output would be expected in more productive shallower habitats (Keats et al. 1984, Byrne 1990, Lamare et al. 2002). However, in shallow waters it is likely to expect a higher mortality rate than in deeper areas due to both the effect of predation and fisheries.

Since sea urchins can also feed on encrusting algae, benthic microalgae, phytodetritus and small invertebrates (Kelly et al. 2001), they can survive in deeper habitats (Gage \& Tyler 1985). Moreover, there are zones where macrophyte detritus may represent an important source of energy, capable of sustaining productive communities in deep habitats (Harrold et al. 1998, Vetter \& Dayton 1998, Dierssen et al. 2009).

Despite their low abundances and slow individual growth rates, patches inhabiting sub-optimal habitats can play a fundamental role in the persistence of the population in space and time (Basch \& Tegner 2007, Kerr et al. 2010a). These areas may provide higher environmental stability, resulting in higher survival rates compared to populations living in shallower waters affected by overfishing.

While the reproductive schedule of $L$. albus changes over its latitudinal range (Bay-Schmith et al. 1981, Guisado
\& Castilla 1987, Zamora \& Stotz 1994, Arias et al. 1995, Guisado et al. 1998), two seasonal peaks of gonadic maturation have been described: a first and larger peak during mid-spring, followed by a secondary peak in late summer (Bay-Schmith et al. 1981, Kino \& Agatsuma 2007). According to Bay-Schmith et al. (1981) and Bückle et al. (1977), only the first maturation peak produces a massive spawning event, while the secondary peak may be reabsorbed to conserve energy for other physiological demands during the following autumn and winter. This reabsorption process has also been described for other sea urchin species in temperate climates (Byrne 1990). Differences in both the gonad maturation schedule and fecundity have been observed over the bathymetric gradient down to $25 \mathrm{~m}$ and are related to decreasing food availability with depth as observed in other sea urchin species and habitats (Keats et al. 1984, Byrne 1990, Rogers-Bennett et al. 1995, Basch \& Tegner 2007).

The current abundance of deep L. albus patches (deeper than 20-30 m) and their relative contribution as a source of eggs and larvae that may maintain the viability of populations exploited by hookah divers in shallow habitats (above $30 \mathrm{~m}$ ) has been matter for strong debate by the stakeholders involved in the Chilean L. albus fishery. Information on the abundance and reproductive biology of populations inhabiting deeper waters is, however, very scarce.

The inland seas of southern Chile $\left(41^{\circ} \mathrm{S}\right.$ to $\left.56^{\circ} \mathrm{S}\right)$ correspond to a large archipelagic region dominated by fjords and channels, which receive substantial freshwater inputs from coastal regions. Circulation patterns in the Chilean inland sea have been described as being highly influenced by tides, winds, density gradients and local topographic features such as sills, constrictions, channels and embayments (e.g., Silva et al. 1998, Valle-Levinson \& Blanco 2004, Cáceres et al. 2006, 2008, Aiken 2008). All these factors interact to form retention and dispersion zones of high biological value (e.g. Valle-Levinson et al. 2001, Molinet et al. 2006, Castro et al. 2011). Considering these oceanographic features it is possible to hypothesize the existence of deep-sea urchin patches reproductively active in Chilean inland seas.

The objectives of this study were (i) to verify the existence of deep and reproductively active $L$. albus patches in two fishing areas within the Chilean Inland Sea, and (ii) compare their reproductive features over the 0-100 m bathymetric gradient, including gonadic index, spawning and reproductive capacity for egg production. 


\section{MATERIALS AND METHODS}

\section{STUDY AREA}

The study was conducted in two areas of the Northwest Patagonian inland sea (Fig. 1A): the southeast portion of Chiloé Island ( $43^{\circ} 08^{\prime} \mathrm{S}-43^{\circ} 25^{\prime}$ 'S) close to Quellón, the most important landing port of the northwest Chilean Inland Sea L. albus fishery (hereafter Quellón), and the Guaitecas Archipelago (43⒌ $54^{\prime} \mathrm{S}-44^{\circ} \mathrm{S}$ ), close to Melinka, the second largest landing port of this fishery in the area.

Quellón is a system formed by three main channels, with a main depression within the Laitec Channel, which reaches a maximum depth of $110 \mathrm{~m}$ and covers about 2 $\mathrm{km}^{2}$ (about $5 \%$ of this system). A particular alternation of upwelling and downwelling fluxes over a rise in this depression has been identified by Cáceres et al. (2008). Guaitecas is a system formed by several channels with maximum depths of around $80 \mathrm{~m}$. Both systems have a layered water column with salinities between 27 and 33 in the top 50 m (Silva et al. 1998, Cáceres et al. 2008, Molinet et al. 2008), and exhibit abrupt changes in their coastal morphology and bathymetry (Gobierno de Chile 2005, Quiroz \& Duhart 2006).

After an exploratory survey (described below) three fixed stations were selected in Quellón: Canal Chaiguao,
Laitec depression (in the Laitec Channel) and south of San Pedro Island (Fig. 1B), and three others in Guaitecas: Westhoff Island, west of Leucayec Island, and west of Clotilde Island (Fig. 1C). The criteria applied for selecting fixed stations for further biological sampling was defined as a minimum average of 30 individuals per exploratory transect of $100 \mathrm{~m}$.

\section{EXPLORATORY SURVEY}

In order to achieve our objective of finding deep sea urchin patches in the study areas, exploratory surveys were carried out based upon a minimum of four 100-m long video counting transects per station, conducted by means of a towed SeaViewer video camera (resolution: 520 lines), equipped with a variable intensity LED lighting system. The camera was connected to a console at the surface for visualization and recording. Nominal towing speed ranged between 1 and 2 knots. The depth and the start and end points of each transect were registered using a Garmin 492s GPS-sounder. The distance traveled was obtained by recording the navigation track of each transect from the GPS, marking the start and end point for each depth stratum, as well as landmarks such as the first appearance and end point of each sea urchin patch. The field of view width, and therefore the segment sampled, was estimated based on light levels at each depth as well
Figure 1. A) Study area in southern Chile highlighting Quellón area (frame located north of Corcovado Gulf) and Guaitecas area (frame located south of Corcovado Gulf). B) and C) show Quellón and Guaitecas at 1: 150.000, for details of sampled stations. Dashed circles are sampling stations. Dashed circle on the Laitec channel corresponds to the Laitec depression. The line that crosses the Corcovado Gulf defines the regional administrative political border between the Los Lagos and Aysén regions / A) América del Sur, destacando en gris el territorio Chileno y la ubicación del área de estudio en un recuadro. B) Área de estudio en la Isla de Chiloé e Islas Guaitecas. C) Estaciones de muestreo en la zona de Quellón y D) estaciones de muestreo en Guaitecas. Círculos con líneas diagonales muestran los sitios específicos de muestreo en cada área. La línea a través del Golfo Corcovado indica el límite administrativo de las regiones de Aysén y de Los Lagos

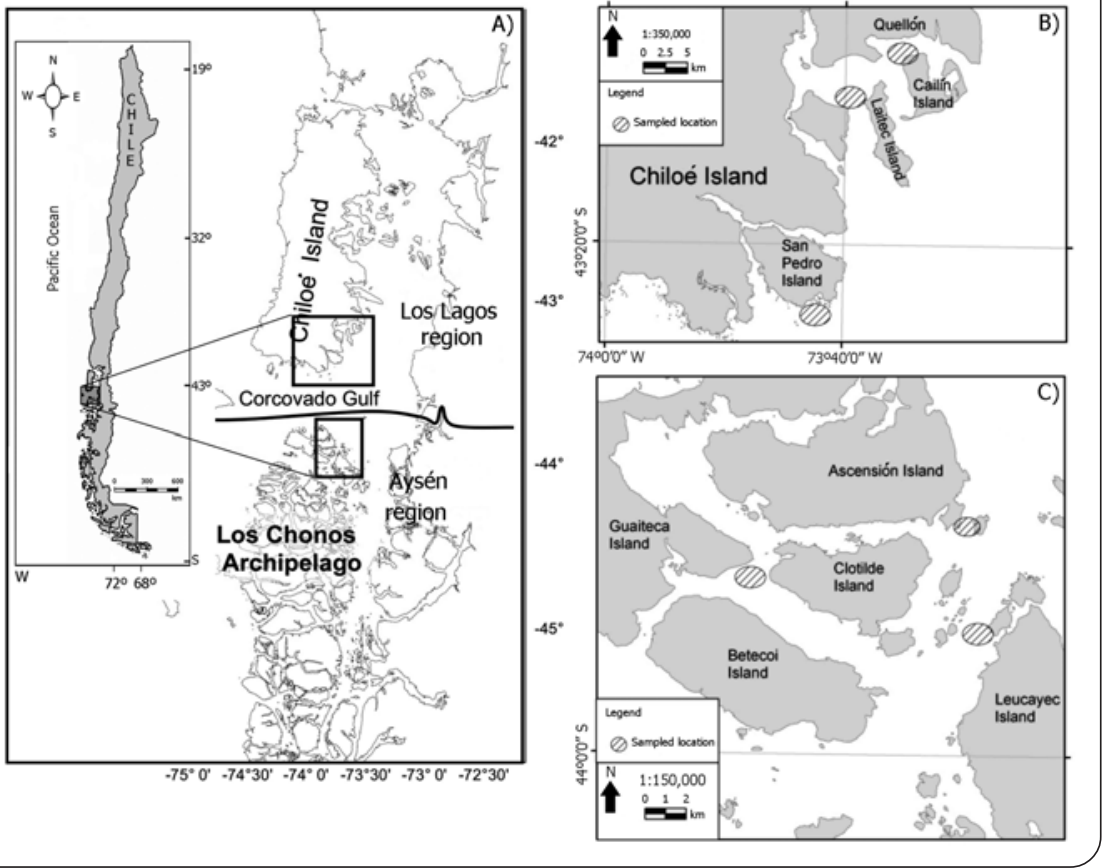


as the presence of sea urchins that were collected and subsequently measured. The estimation was: one meter wide for stratum 1 (0-10 m) and stratum 2 (11-30 m), $0.5 \mathrm{~m}$ for stratum 3 (31-60 m) and 0.3 m for stratum 4 (61-100 m). The abundance in each transect was estimated considering the number of urchins and the area swept by the camera per transect.

\section{SAMPLING FOR REPRODUCTIVE STUDIES}

Four depth strata were defined at each sampling station: 0-15 m, 16-30 m, 31-60 m, and 61-100 m depth. Between 100 and 150 individuals were collected at each of the three deepest strata, whenever possible, by means of a 'chain sweep' trawl with a $1 \mathrm{~m}^{2}$ mouth and $2 \mathrm{~m}$ length (Campagna et al. 2005), which was towed over a distance of 100-200 $\mathrm{m}$. Samples from the $0-15 \mathrm{~m}$ stratum were collected by artisanal fishermen divers, because the irregular bottom did not allow for the proper use of the chain sweep trawl. Divers randomly collected all sea urchin individuals (irrespective of their sizes) visible in the sampled area until a net bag designed to accommodate approximately $40 \mathrm{~kg}$ of urchins was filled.

None of the Guaitecas stations had sea urchin patches below $50 \mathrm{~m}$ in sufficient abundance to fulfill the previously established criteria. A small group of 5 individuals was nonetheless collected from a depth of $70 \mathrm{~m}$ in November 2008 and included in the induced spawning experiments of that month.

Four sampling surveys were carried out at 45-60 day intervals (September 2008, November 2008, January 2009, and March 2009). This period corresponded to the $L$. albus spawning season, as described in the literature (BaySchmith et al. 1981, Guisado 1995, Kino \& Agatsuma 2007). The samples collected were stored in labeled polyethylene bags and transported live to the laboratory where they were processed and where spawning assays were conducted.

\section{SAMPLE PROCESSING}

All individuals collected were measured for test diameter with a knife-edged caliper ( $0.1 \mathrm{~mm}$ precision) and wet weighed with a digital balance ( $0.1 \mathrm{~g}$ precision). From each sample, a total of 40 adult individuals were selected, using a minimum size criterium of $55 \mathrm{~mm}$ test diameter (TD), considering that at this TD at least $80 \%$ of the urchins are reproductively mature according to BaySchmith et al. (1981) and Lozada \& Bustos (1984). Thirty of these 40 individuals were sexed and the wet weight of their gonads was determined. The gonadic index (GI) was individually calculated using the following relationship: GI= Gonad wet weight / Total wet weight (Gonor 1972).

Sex determination was carried out on fresh gonad smears, under a microscope at a magnification of 100x. Spawning was induced in the remaining 10 individuals from each sub-sample. Individuals were rinsed with seawater, measured, weighed and put into individual transparent flasks of 100 to $300 \mathrm{~mL}$. Each individual was then injected with $6 \mathrm{~mL}$ of $\mathrm{KCl} 0.5 \mathrm{M}$ via the peristomal membrane, and left for 90 min (Zamora \& Stotz 1994, Bustos \& Olave 2001, Barahona et al. 2003). After this period, three $10-20 \mu \mathrm{L}$ sub-samples were taken from the flask, and deposited in a Sedgewick Rafter counting chamber, where oocytes were counted under a microscope at 200x. The total number of released oocytes per spawned female $\left(N_{0}\right)$ was estimated using the following formula:

$$
N_{0}=\frac{\bar{X} v_{T}}{v}
$$

where $\bar{X}$ is the average of the three counts in the Sedgewick Rafter chamber, $\mathrm{V}_{T}$ is the total volume of the flask in which the female spawned, and $v$ is the volume of the sample observed in the Rafter chamber. For standardization purposes, $N_{o}$ was divided by the wet weight of the individual sea urchin before the statistical analysis. When spawning induction failed, individuals were dissected and sexed.

\section{Data analysis}

Because L. albus from the deepest stratum were only sampled on a regular basis in Quellón, and in order to keep sampling period and location as fixed effects, two designs for each analysis were utilized: (i) a model that included the three most shallow strata in both sampled areas (Quellón and Guaitecas) for studying GI variability, the success/failure of spawning and the number of oocytes $\mathrm{g}^{-1}$ of urchin, and (ii) a model which included all the strata only for area Quellón to study the variables described in (i).

The gonadic index data, being a proportion, were transformed by applying an arcsine transformation. Then, normality of residuals and homogeneity of variances of the transformed variable was assessed using the ShapiroWilk test (Zar 1999), and an ANOVA was used to test differences between zone, month, sex and stratum means (Zar 1999). 
The binary response variable spawning induction success/failure was analyzed using as predictors the variables depth strata, month, and location by applying a GLM binomial model (link logit), and the variable providing the best fit was chosen according to Akaike's information criterion (AIC) (Akaike 1974). The AIC is an estimator of expected relative Kullback-Leibler information based on the maximized log-likelihood function, corrected for asymptotic bias (Burnham \& Anderson 2004). The selected model is one that has a lower value of AIC, defined by:

AIC $=(-2) \log ($ maximized lokelihood $)+2$ (the asymptotic bias correction term).

When September 2008 data on spawning induction success were available, they were only included in the binomial model, where they helped to assess the degree of synchrony between depth strata and locations.

The statistical conclusions from GI and spawning induction models were verified by visually exploring a graphical display of the fitted values and residuals: (i) a plot of deviance residuals versus the fitted values, (ii) a plot of the square root of the absolute deviance residuals versus the linear predictor values, (iii) a plot of the response versus the fitted values, and (iv) a normal quantile plot of the Pearson residuals (q-q plots) (McCullagh \& Nelder 1989).

In the case of the spawning induction results, the large number of zero values made it impossible to apply standard ANOVA or mean comparison approaches, as normality assumptions had been severely violated. If zeros had been ignored a relevant part of the information would have been lost. Moreover, both the spawning induction success and the number of oocytes released were variables of interest. Hence we used a delta-gamma general linear model (GLM) approach (sensu Stefansson 1996) based upon the Aitchison-Pennington method (Aitchison 1955, Pennington 1983). Here the observable positive density response (number of oocytes $\mathrm{g}^{-1}$ of urchin) $(\hat{d})$ is considered a random variable with a spike in probability mass at the origin. As a consequence, $\left(\hat{d}_{\mathrm{p}}\right)$ is calculated as a conditional mean, by ignoring null observations. The latter are, however, used to produce an independent estimate of the probability of spawning success in each sample $(\hat{p})$ and then combined into a corrected estimate for the response variable $\hat{d}_{\mathrm{c}}$ following the relationships: $\hat{d}_{\mathrm{c}}=\hat{p} \times \hat{d}$, and their variance:

$$
v \hat{d}_{c}=\hat{p}^{2} \times v\left(\hat{d}_{p}\right)+v(\hat{p}) \times \hat{d}_{p}^{2}
$$

Corrected means $\left(\hat{d}_{\mathrm{c}}\right)$ were calculated using a general linear model procedure (Wolfinger \& O’Connell 1993), by assuming a gamma distribution of errors and using a loglink function. The gamma distribution of errors was selected because greater flexibility in accommodating nonnormal datasets (McCullagh \& Nelder 1989). A log-link function was needed to fulfill distribution assumptions.

Spawning success/failure data from our samples were analyzed as a dichotomous variable (0/1) used to estimate $\bar{p}(d>0)$ within a general linear model procedure. For this, we assumed a binomial distribution of errors and used a logit-link function (Kleinbaum et al. 1998).

Alternative models based upon competing explanatory variables were selected as those yielding the smallest sum of Akaike's information criteria (AIC) computed from the binomial and gamma models that corresponded to each set of variables being tested. These models were assessed through a likelihood ratio test using the lmtest package in R 2.1.13 (Zeileis \& Hothorn 2002). All general linear models were constructed and tested using the statistical and programming software R 2.1.13 (Venables \& Ripley 2002, Fox \& Sanford 2010).

\section{RESUlts}

We explored a total of 49 stations in Quellón and 78 stations in Melinka (Fig. 2). Given the bathymetric characteristics of the study area (higher proportion of shallow versus deeper zones), a greater number of transects were carried out between 0 and $60 \mathrm{~m}$ depth (see Moreno et al. 2011). As a result of these explorations higher urchin abundances were observed in Guaitecas area and in shallow habitats (Table 1). Only one sea urchin patch (around 54,000 individuals) was found at a depth greater than $60 \mathrm{~m}$, which occurred in the Canal Laitec depression and represented about $0.2 \%$ of the total estimated abundance in Quellón Area. Molinet et al. (2009) and Moreno et al. (2011) provide detailed abundance, size distribution data, and substratum types inhabited by L. albus at different depths within the studied fishing areas.

\section{GONADIC INDEX}

The GI for the first analysis (0-60 m depth, all months and both areas) showed significant differences between areas, depth strata, months, and sex (ANOVA, $P<0.05$ ). The highest GI median value corresponded to females sampled from the shallowest strata at Quellón, during September 


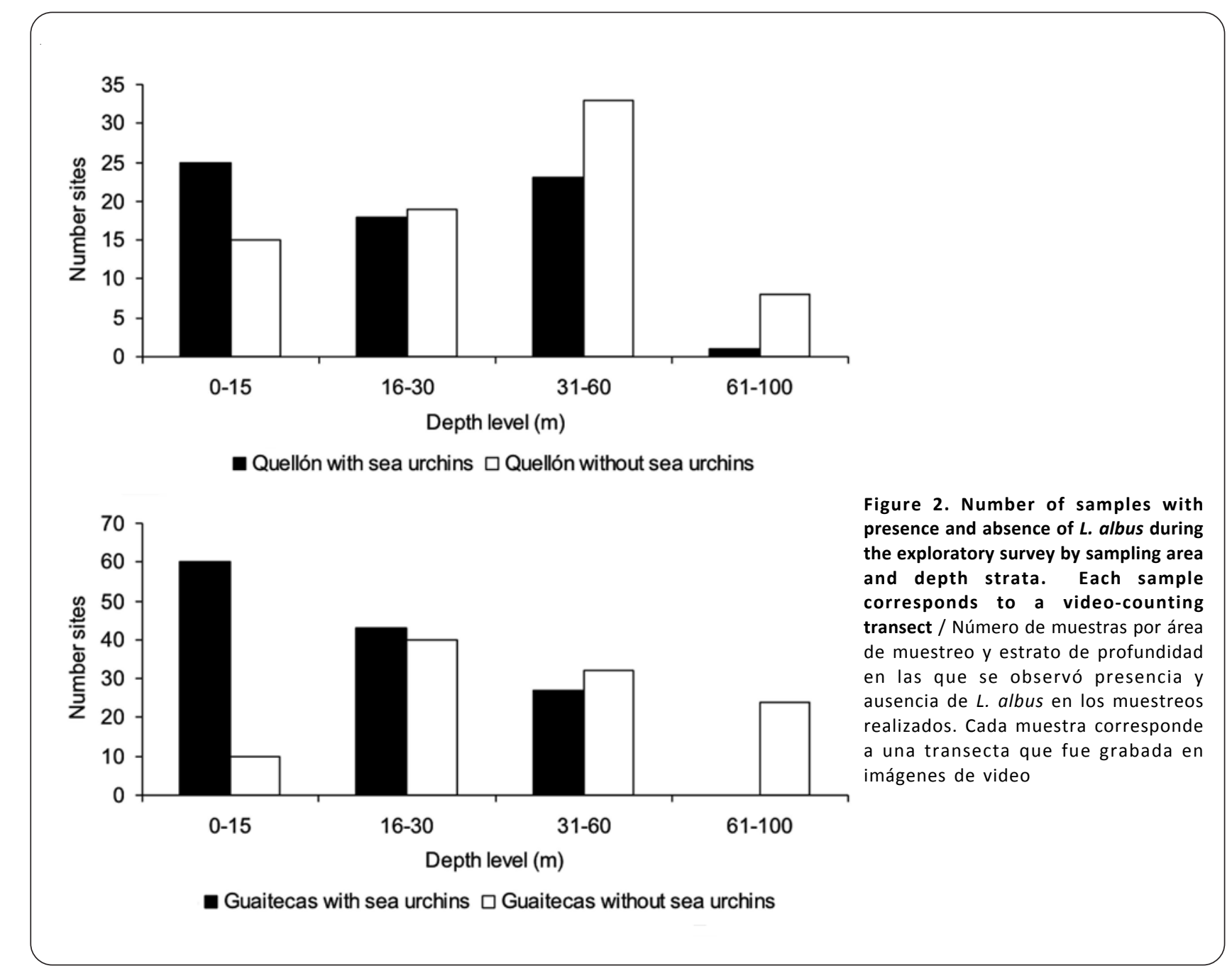

Table 1. Loxechinus albus estimated abundance (number of sea urchins) and percentage of urchins on each depth strata, and study area (from Molinet et al. 2009) / Loxechinus albus, abundancia estimada (número de erizos) y porcentaje de erizos en cada estrato de profundidad y área de estudio (según Molinet et al. 2009)

\begin{tabular}{llcccc}
\hline \multirow{2}{*}{ Area } & & \multicolumn{5}{c}{ Observed abundance per depth stratum } \\
& & 0 to $10 \mathrm{~m}$ & 11 to $30 \mathrm{~m}$ & 31 to $60 \mathrm{~m}$ & 61 to $100 \mathrm{~m}$ \\
\hline \multirow{2}{*}{ Quellón } & \multirow{2}{*}{ Abundance } & $65,870,694$ & $15,773,764$ & 740,402 & 54,342 \\
& Percentage & 79.90 & 19.03 & 0.50 & 0.02 \\
& Abuaitecandance & $347,756,380$ & $7,218,463$ & 649,957 & 546 \\
& Percentage & 97.79 & 2.03 & 0.18 & 0.00 \\
\hline
\end{tabular}


2008. The lowest median value was observed in the same area and month, but at the deepest strata (Fig. 3, Table 2). The GI for the second analysis (only the Quellón area, sex, all the depth strata and months) showed significant differences (ANOVA, $P<0.05$ ), where the median GI in samples from 31-60 m showed significant differences with respect to all other strata (Table 2). No significant differences in male/female ratios were observed (ANOVA, $P>0.05)$ in the first three strata $(0-60 \mathrm{~m})$. Nevertheless, significant differences were observed (ANOVA, $P<0.05$ ) in the proportion of females (30\%) to males (70\%) found in samples from Quellón collected from the 60-100 m depth stratum (Fig. 4, Table 2).

\section{SPAWNING}

Induced spawning success for the first three strata was significantly affected by month, sampling area, test diameter and the interactions between month and depth strata, and between month and sampling area (Table 3, Fig. 5). The results indicated that the spawning success was scarce in September, while the greatest spawning success occurred between November and March, depending upon month, depth strata and sampling area. Loxechinus albus from Guaitecas did not respond to induction in September (Fig 5), but showed a similar pattern to Quellón during the rest of the season. Spawning induced in Quellón showed an asynchrony between depth strata, where the highest success ratios tended to occur later in the season at the deepest strata (Fig. 5, Table 3). Sex was not a significant factor in explaining induced spawning success variability.
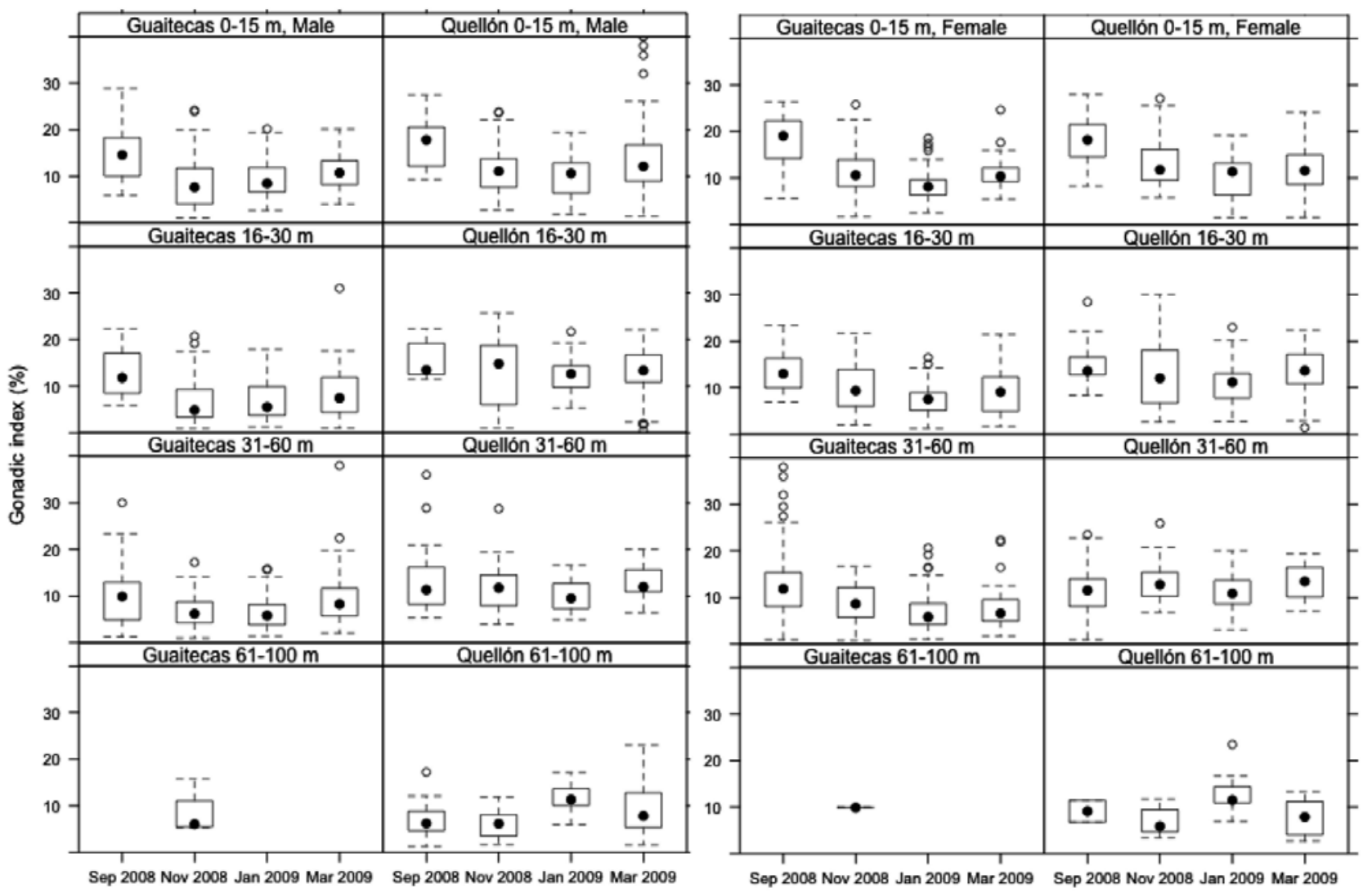

Figure 3. Boxplot of the gonad index of $L$. albus (separated by males and females) per study area and depth strata. Black dots indicate medians; boxes indicate percentiles 25 and 75 . Whiskers indicate $5^{\text {th }}$ and $95^{\text {th }}$ percentiles. White dots indicate outliers / Box plot de la variación del índice gonádico de L. albus (separados para machos y hembras) por área y estrato de profundidad. Puntos negros indican la mediana, cuadros representan los percentiles 25 y 75 , barras de error muestran el percentil 5 y $95 \%$. Puntos blancos indican valores fuera de rango 


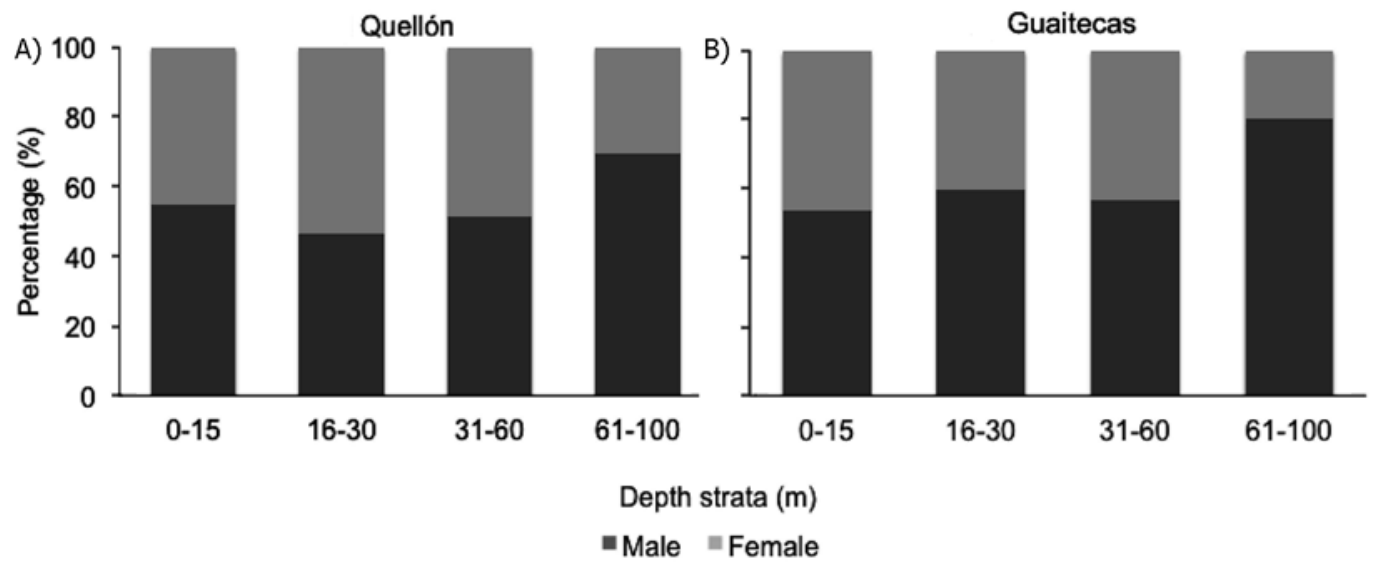

Figure 4. Sex ratios for L. albus per area and depth strata for the whole sampling period from A) Quellón and B) Guaitecas/ Proporción de sexos para L. albus por área y estrato de profundidad para todo el periodo de muestreo de A) Quellón and B) Guaitecas

Table 2. ANOVA table for the variation in arcsine transformed gonadic index observed in Loxechinus albus sampled between September 2008 and March 2009. Significant effects are highlighted with asteriks / ANOVA para la variación del índice gonádico, transformado usando la función Arcoseno, en Loxechinus albus muestreados entre septiembre de 2008 y marzo de 2009. Efectos significativos son destacados con asterisco

\begin{tabular}{lccccc}
\hline $\begin{array}{c}\text { Loxechinus albus } \\
\text { GI }\end{array}$ & $\begin{array}{c}\text { Degree of } \\
\text { freedom }\end{array}$ & $\begin{array}{c}\text { Sum of } \\
\text { square }\end{array}$ & $\begin{array}{c}\text { Mean } \\
\text { square }\end{array}$ & $\mathrm{F}$ & $P(>\mathrm{F})$ \\
\hline 0-60 m depth & & & & & \\
$\quad$ Depth strata & 2 & 0.4158 & 0.20791 & 29.3 & $2.68 \mathrm{E}-13^{*}$ \\
Area & 1 & 1.5038 & 1.50376 & 211.921 & $2.20 \mathrm{E}-16^{*}$ \\
Sex & 1 & 0.1736 & 0.17357 & 24.46 & $8.11 \mathrm{E}-07^{*}$ \\
Month & 3 & 1.748 & 0.58268 & 82.116 & $2.20 \mathrm{E}-16^{*}$ \\
Residuals & 2389 & 16.952 & 0.0071 & & \\
0-100 m depth & & & & & \\
from Quellón & & & & & \\
$\quad$ Depth strata & 3 & 0.4627 & 0.154217 & 22.0159 & $6.90 \mathrm{E}-14^{*}$ \\
Sex & 1 & 0.0091 & 0.009051 & 1.2922 & 0.2559 \\
$\quad$ Month & 3 & 0.2421 & 0.080685 & 11.5186 & $1.90 \mathrm{E}-07^{*}$ \\
Residuals & 1223 & 8.5669 & 0.007005 & & \\
\hline
\end{tabular}




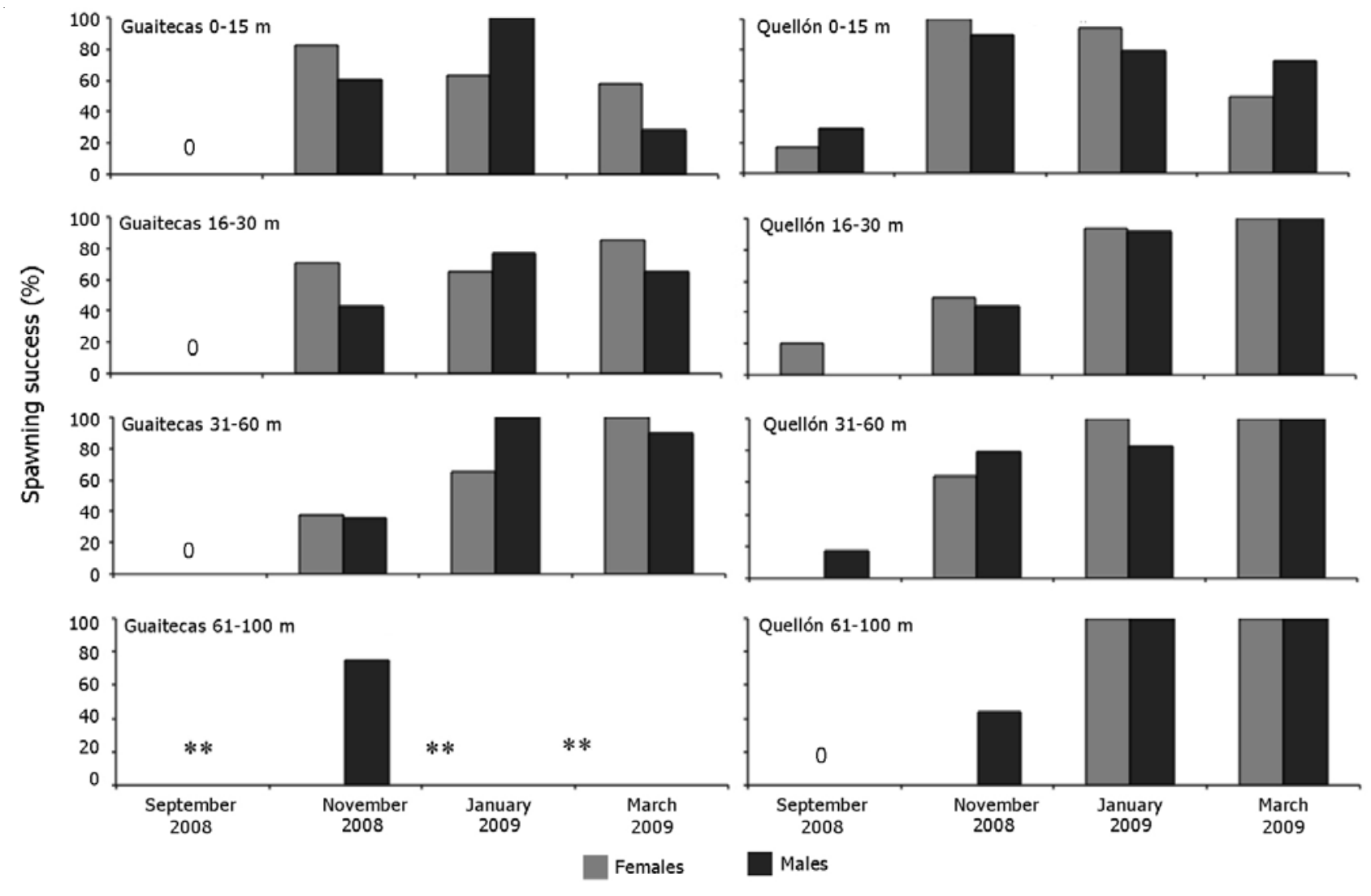

Figure 5. Spawning induction success in L. albus females and male per area, depth strata, for all sampling periods. Zero indicates spawning failure, while double asterisk indicates no urchins were available for spawning induction experiments / Éxito en la inducción al desove en machos y hembras de L. albus por área y estrato de profundidad para todo el periodo de muestreo. Ceros indican fracaso en la inducción al desove, mientras que doble asterisco indica que no fueron recolectadas hembras para los experimentos de inducción al desove

Table 3. Deviance analysis of the general linear model (binomial family, logit link) used to evaluate spawning induction success in Loxechinus albus, injected with $\mathrm{KCl}$. Two designs for each analysis are show: Spawning success between 0-60 $\mathrm{m}$ depth, for the entire study period and both study areas, and spawning success for $L$. albus from Quellón over the entire bathymetric gradient. The best model is one that shows highest likelihood ratio relative to other models and their $\chi^{2} P<0.05 /$ Análisis de Desvianza del modelo general lineal (familia binomial, link logit) usado para evaluar el éxito en la inducción al desove en Loxechinus albus inyectados con $\mathrm{KCl}$. Se muestran dos diseños por cada análisis: éxito de desove entre 0-60 $\mathrm{m}$ de profundidad, para todo el periodo de estudio y ambas áreas de estudio, y éxito de desove para erizos de Quellón en el gradiente batimétrico 0 a $100 \mathrm{~m}$ de profundidad. El mejor modelo muestra un mayor valor de razón de verosimilitud y su $\chi^{2} P<0,05$

\begin{tabular}{lccc}
\hline $\begin{array}{l}\text { Loxechinus albus } \\
\text { spawning success }\end{array}$ & Likelihood-ratio & $\begin{array}{c}\chi^{2} \text { Degree } \\
\text { of freedom }\end{array}$ & $P\left(>\chi^{2}\right)$ \\
\hline 0-60 m depth & & & \\
Month & 276.521 & 3 & $2.20 \mathrm{E}-16^{*}$ \\
Depth strata & 0.516 & 2 & 0.772697 \\
Area & 24.796 & 1 & $6.37 \mathrm{E}-07^{*}$ \\
Test diameter & 9.251 & 1 & $0.0023^{*}$ \\
Month * Depth strata & 57.254 & 6 & $1.62 \mathrm{E}-10^{*}$ \\
Month * Sampled area & 9.6 & 3 & $0.0222^{*}$ \\
0-100 m depth from Quellón & & & \\
Month & 153.45 & 3 & $2.20 \mathrm{E}-16^{*}$ \\
Depth strata & 1.685 & 3 & 0.6402 \\
Test diameter & 5.867 & 1 & $0.01543^{*}$ \\
Month * Depth strata & 52.188 & 9 & $4.17 \mathrm{E}-08^{*}$ \\
\hline
\end{tabular}


As released oocytes were not estimated for the first spawning induction experiments (September 2008), related variables were only available for November 2008, January 2009, and March 2009. The greatest numbers of released oocytes/female were recorded in March in both areas, at most sampling strata, with a maximum average of nearly 5 million oocytes/female in Quellón (Laitec depression), at the 16-30 m depth stratum (Table 4). In November and January, the average number of released oocytes/female ranged between 280,000 and 797,000 across areas and depth strata, except at the Quellón 31-60 m depth stratum where they reached the value of $1,483,000$ released oocytes/female (Table 4).

The delta-gamma general linear model, which included only the three shallower strata in Quellón and Guaitecas, built to explain variability in the number of oocytes $\cdot \mathrm{g}^{-1}$, showed that month and depth strata, explained significant proportions of observed variability (Table 5). On the other hand, the delta-gamma general linear model which included all the strata in Quellón showed that only month explained a significant proportion of the observed number of oocytes $\cdot \mathrm{g}^{-1}$ variability (Table 6 ), showing that corrected number of oocytes $\cdot \mathrm{g}^{-1}$ were highest in March 2009 (Fig. $6 \mathrm{~A})$. It was possible to observe general pattern characterized by a induced spawning success that started earlier in Quellón and at shallower depths and increased in March, at intermediate depths, both in Quellón and Guaitecas (Fig 6A and 6B). Corrected number of oocytes $\cdot \mathrm{g}^{-1}$ in urchins from the deepest depths of the Quellón depression was recorded only from January to March 2009 (Fig. 6C), but the delta-gamma model results showed that depth was significant only for the spawning success (Table 6), and the number of oocytes was only affected by month.

\section{Discussion}

Most $L$. albus patches were confined to shallow areas (0$10 \mathrm{~m}$ depth), patches between 30 and $60 \mathrm{~m}$ depth were rare, and only one patch was found below $60 \mathrm{~m}$ (Laitec patch). Regardless of the depth strata, densities were low across the whole study area at the time this survey was carried out, ranging between 1 and 15 individuals $\cdot \mathrm{m}^{-2}$ (Molinet et al. 2009, Moreno et al. 2011). These low densities could be the result of the high fishing pressure that affects the study area, with recorded landings between 3,000 and 4,500 ton year ${ }^{-1}$ in Quellón, and between 1,800 and 2,500 ton year ${ }^{-1}$ in Guaitecas in the last 5 years (Molinet et al. 2009, Moreno et al. 2011).

Table 4. Mean numbers of oocytes spawned (thousand of oocytes \pm standard deviation) by Loxechinus albus females induced to spawn by $\mathrm{KCl}$ injection by depth, month and area / Promedio de ovocitos desovados (miles de ovocitos \pm desviación estandar) por área y por mes para hembras de Loxechinus albus inducidas al desove por inyección de $\mathrm{KCl}$

\begin{tabular}{clcc}
\hline Depth stratum $(\mathrm{m})$ & Month & Guaitecas & Quellón \\
\hline \multirow{2}{*}{$0-15$} & September 2008 & & \\
& November 2008 & $367 \pm 488$ & $683 \pm 740$ \\
& January 2009 & $345 \pm 749$ & $588 \pm 707$ \\
& March 2009 & $2,402 \pm 4,554$ & $1,536 \pm 1,852$ \\
\multirow{5}{*}{$16-30$} & September 2008 & & \\
& November 2008 & $419 \pm 576$ & $797 \pm 1603$ \\
& January 2009 & $280 \pm 301$ & $748 \pm 745$ \\
& March 2009 & $3,603 \pm 4,064$ & $4,993 \pm 5,517$ \\
$31-60$ & September 2008 & & $326 \pm 540$ \\
& November 2008 & $105 \pm 201$ & $1,483 \pm 1042$ \\
& January 2009 & $376 \pm 529$ & $720 \pm 85$ \\
& March 2009 & $1,793 \pm 2,943$ & 0 \\
& September 2008 & & $753 \pm 1181$ \\
& November 2008 & & 0 \\
& January 2009 & & $1,305 \pm 177$ \\
\hline
\end{tabular}


Table 5. Likelihood ratios and $\chi^{2}$ test for explanatory variables selected by the delta-gamma general linear model (GLM) approach used to explain variability in spawning induction results, in both study areas, from November 2008 to March 2009 , and between 0-60 m depth. Results are presented for the logistic sub-model applied to the dichotomous success/failure results and for the log-gamma sub-model applied to the conditional $(n>0)$ number of released oocytes $\mathbf{~}^{-1}$. The best model is one that shows highest likelihood ratio relative to other models and their $\chi^{2} \boldsymbol{P}<0.05$ / Relaciones de verosimilitud y test $\chi^{2}$ para las variables explicatorias seleccionadas por la aproximación delta-gama usada para evaluar la variabilidad en los resultados de inducción al desove en ambas áreas de estudio entre noviembre de 2008 y marzo de 2009 en los estratos 0-15, 15-40 y 40-60 m de profundidad. Los resultados muestran (arriba) el submodelo aplicado a la dicotomía éxito/fracaso en el desove y (abajo) el submodelo log-gamma, aplicado a la condición $(n>0)$ número de ovocitos liberados por gramo de hembra . El mejor modelo muestra un mayor valor de razón de verosimilitud y su $\chi^{2} P<0,05$

\begin{tabular}{lccc}
\hline Loxechimus albus & Likelihood-ratio & $\begin{array}{c}\chi^{2} \text { Degree } \\
\text { of freedom }\end{array}$ & $P\left(>\chi^{2}\right)$ \\
\hline $\begin{array}{l}\text { Spawning induction success } \\
\text { between 0-60 m depth }\end{array}$ & & & \\
Month & 3.2464 & 2 & 0.197 \\
Depth strata (3 strata) & 0.016 & 2 & 0.992 \\
Area & 9.3608 & 1 & $0.002^{*}$ \\
Month * Depth strata & 22.8801 & 4 & $0.0001^{*}$ \\
Month * Area & 5.928 & 2 & 0.051 \\
Positive number of oocytes g & & & \\
between 0-60 m depth & & & \\
Month & & 2 & $2.20 \mathrm{E}-16^{*}$ \\
Depth strata (3 strata) & 16.509 & 2 & $0.00026^{*}$ \\
Area & 1.452 & 1 & 0.2281613 \\
Month * Depth strata & 6.134 & 4 & 0.1893828 \\
Month * Area & 4.831 & 2 & 0.089306 \\
\hline
\end{tabular}

Table 6. Likelihood ratios and $\chi^{2}$ test for explanatory variables selected by the delta-gamma general linear model (GLM) approach used to explain variability in spawning induction results, in Quellón, from November 2008 to March 2009, and over the entire bathymetric gradient 0-100 m depth. Results are presented for the logistic sub-model applied to the dichotomous success/failure results and for the log-gamma sub-model applied to the conditional $(n>0)$ number of released oocytes $\mathrm{g}^{-1}$. The best model is one that shows highest likelihood ratio relative to other models and their $\chi^{2} \boldsymbol{P}<0.05$ / Relaciones de verosimilitud y test $\chi^{2}$ seleccionadas por el modelo GLM delta-gamma utilizado para evaluar la variabilidad en la inducción al desove y el número de ovocitos en Quellón desde noviembre de 2008 a marzo de 2009 en el gradiente batimétrico de 0 a $100 \mathrm{~m}$ de profundidad. Los resultados muestran el submodelo aplicado a la dicotomía éxito/fracaso en el desove y el submodelo log-gamma, aplicado a la condición $(\mathrm{n}>0)$ número de ovocitos liberados por gramo de hembra. El mejor modelo muestra un mayor valor de razón de verosimilitud y su $\chi^{2} P<0,05$

\begin{tabular}{cccc}
\hline \multicolumn{1}{c}{ Loxechinus albus } & Likelihood-ratio & $\begin{array}{c}\chi^{2} \text { Degree of } \\
\text { freedom }\end{array}$ & $P\left(>\chi^{2}\right)$ \\
\hline $\begin{array}{l}\text { Spawning induction success } \\
\text { between 0-100 m depth from Quellón }\end{array}$ & & & \\
Month & 11.3114 & 2 & $0.003^{*}$ \\
Depth strata (4 strata) & 0.2601 & 3 & 0.967 \\
Month * Depth strata & 21.5997 & 6 & $0.001^{*}$ \\
& & & \\
Positive number of oocytes g & & & \\
between 0-100 m depth from Quellón & & 2 & $1.86 \mathrm{E}-07^{*}$ \\
Month & 30.9918 & 3 & 0.096 \\
Depth strata (4 strata) & 6.3388 & 5 & 0.29218 \\
Month * Depth strata & 6.1469 & & \\
\hline
\end{tabular}



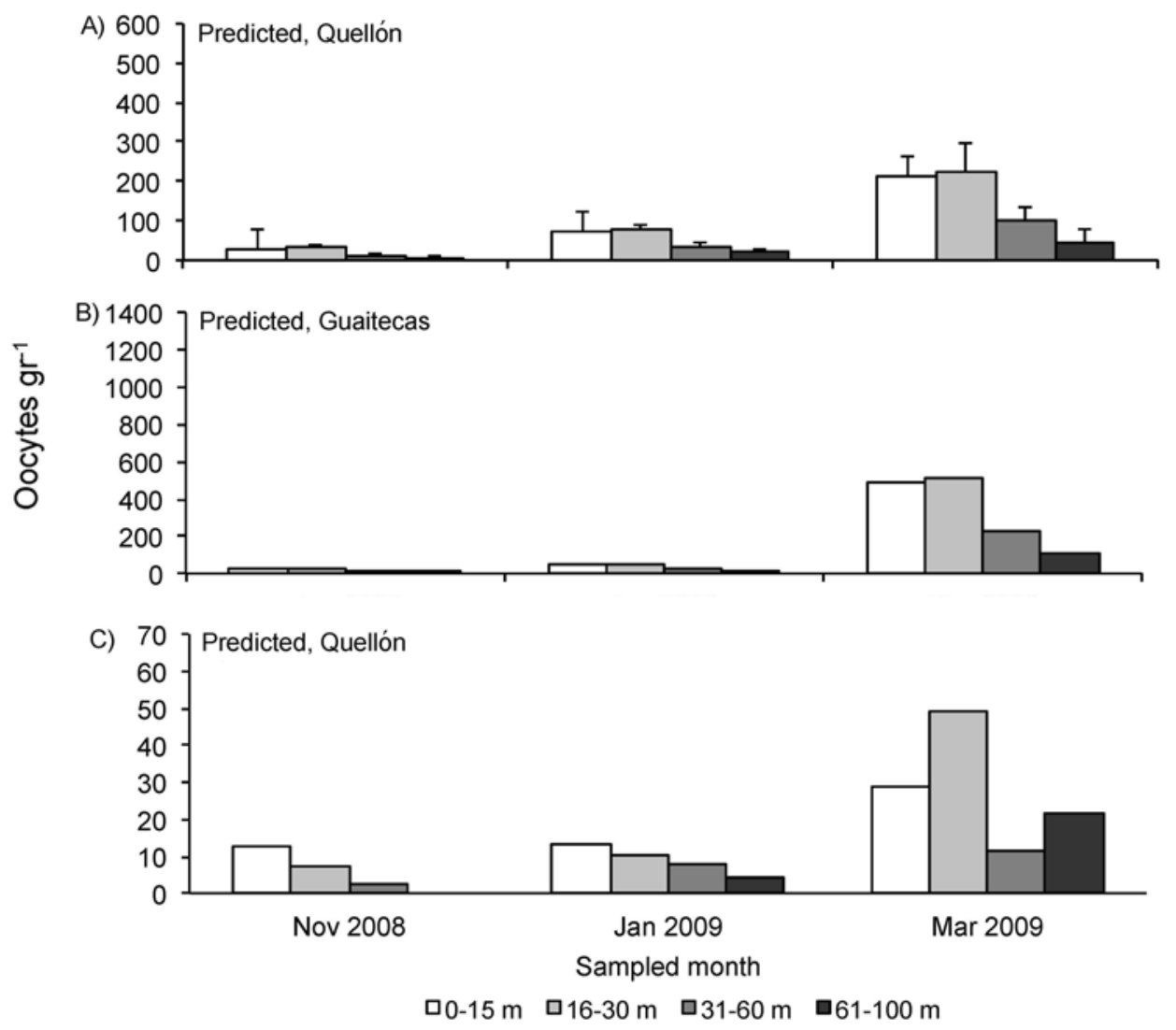

Figure 6. Corrected mean number of oocytes $\mathrm{g}^{-1}$ estimated for $L$. albus females induced by $\mathrm{KCl}$ injection from A) Quellón and B) Guaitecas areas in the first three strata and between November 2008 and March 2009. C) Corrected mean number of oocytes $\mathrm{g}^{-1}$ estimated for $L$. albus females induced by $\mathrm{KCl}$ injection from the four strata studied at Quellón. Error bars show standard errors / Promedio corregido del número de ovocitos $g$ ${ }^{1}$ estimado para hembras de L. albus inducidas al desove utilizando $\mathrm{KCl}$ en las áreas de A) Quellón y B) Guaitecas en los primeros tres estratos, entre noviembre de 2008 y marzo de 2009. C) Promedio corregido del número de ovocitos $\mathrm{g}^{-1}$ estimado para hembras de $L$. albus inducidas al desove en el área de Quellón en los cuatro estratos estudiados. Las barras de error muestran los errores estándar

We found spatial and temporal differences in GI and spawning induction results. Median GI observed for $L$. albus showed higher median values during September, except for samples collected below $30 \mathrm{~m}$ in Quellón, where these indices peaked during January. The GI pattern observed in shallower patches was the same as that reported in the literature for shallow patches of this species in the study area (Bay-Schmith et al. 1981, Kino \& Agatsuma 2007).

The temporary increase in GI observed in January for the 60-100 m depth stratum in the Laitec patch may reflect either a reproductive or an energy storage process, as gonad development has been described to serve the later function in sea urchins (Bay-Schmith et al. 1981). Nonetheless, the positive response to spawning induction in January and March, matched by an evident decrease in median GI between January and March suggests that natural spawning may be occurring at this depth. Furthermore, we did not find significant differences in the corrected number of oocytes $\cdot \mathrm{g}^{-1}$ between deep and shallow patches in the Laitec patch, which suggests that a similar reproductive contribution per individual existed along the entire bathymetric gradient, but a delayed maturity process occurred at this deeper depression.

The observed spatial and temporal heterogeneity in GI and induced spawning success suggests an asynchronous reproductive maturity schedule between the northern and southern sectors of the Corcovado Gulf and across depth strata. Spatial differences in reproductive processes of the urchin $L$. albus were 
previously observed by Bay-Schmith et al. (1981) between the same areas (north and south of the Corcovado Gulf), suggesting that temperature effects could explain these differences. As the temperature throughout the water column of the Laitec Depression is homogeneous (C. Molinet unpubl. data), delayed reproductive maturity in this depression can not be explained by temperature effects. We hypothesize that vertical differences in reproductive timing could result from differential access to an adequate food supply. Persistence, growth and reproductive dynamics of deeper sea urchin patches might depend partially or completely upon top-down pathways driven by saprophyte detritus. Therefore, food supply to deep patches in southern Chile may depend upon two main processes. First, the removal of coastal seaweed by seasonal storms (Moreno \& Sutherland 1982, Buschmann et al. 2004, Hinojosa et al. 2007, 2010), and, second, the interactions between local currents, hollows and rises that can induce significant modifications in the residual flow, as observed in the Laitec Depression by Cáceres et al. (2008). These interactions could promote downwelling and convergence over the hollow as described by Park \& Wang (1991) and Salas-Monreal \& Valle-Levinson (2009) in other systems, supplying organic detritus to deep areas where seaweeds are scarce. These pathways have been described for deep-sea environments adjacent to productive near-shore habitats such as seagrass meadows or kelp forests, where macrophyte detritus removed from these habitats may be transported offshore to deep-sea benthic communities via bottom currents (Harrold et al. 1998, Vetter \& Dayton 1998).

The potential importance of macrophyte detritus as a food supply to the Laitec patch is supported by incidental observations, obtained during two exploratory surveys conducted in September and December 2008 (pers. obs.). While we did not observe detached seaweeds during the first exploratory survey in September, we observed and recorded images with abundant detached seaweeds (Macrocystis pyrifera) down to a depth of $90 \mathrm{~m}$ in the Laitec Depression in December.

The reasons for the observed deviation from a 1:1 sex ratio in the deepest strata of the Laitec patch remains unclear, although it could be related to a higher selective predation on females, as observed in Paracentrotus lividus (Lamarck, 1816) by Gianguzza et al. (2009). Testing this or other alternative hypotheses deserves further study.

We found evidence of $L$. albus reproductive capacity over the entire studied bathymetric gradient $(0-100 \mathrm{~m}$ depth), although urchin patches deeper than $30 \mathrm{~m}$ represent less than $1 \%$ of the studied population. However, given the reported maturity curve of $L$. albus in the study area (Bay-Schmith et al. 1981, Lozada \& Bustos 1984), and of smaller individuals from shallower habitats as observed by Moreno et al. (2011) it is important to examine the reproductive contribution of these deep sea urchins found in the Laitec Depression, and whether that contribution may explain the persistence of patches as heavily exploited as it happens around Quellón.

Considering our results and scientific literature worldwide, at least three hypotheses can be proposed: First, results allow us to propose that recruitment to heavily exploited patches in shallower strata might be partly subsidized by unfished spawning patches from deeper habitats, which could explain the presence of urchin aggregations between 60 and $100 \mathrm{~m}$ depth in Laitec channel. The actual importance of such subsidies would depend, however, upon several factors, besides the mere presence and abundance of reproductively active adults in deep areas. It is possible to identify two main factors, which would be strongly regulated by local oceanographic processes (Cáceres et al. 2008): (i) the amount and timing of food imports (kelp debris) from upper strata, and (ii) the strength and direction of transporting fluxes affecting larvae originated from deep water spawners.

Second, these deeper habitats may not constitute a source, but a sink habitat for local populations (sensu Pulliam 1988), which are colonized by either stochastic dispersal mechanisms or from density-dependent expansions of the population into less suitable habitats (MacCall 1990). In spatially limited environments such active dispersion from source habitats can maintain large populations in distant habitats, which become stable in evolutionary terms (Pulliam 1988). Nonetheless, subpopulations in sink habitats would not be, by definition, self-sufficient. Thus, they would tend to gradually disappear, as shallower areas are over-exploited.

Third, it might be that shallower and deeper patches play complementary roles in increasing the resilience of the population to environmental variability (Kerr et al. 2010a). Under this portfolio effect hypothesis (Secor et al. 2009), sub-populations inhabiting less suitable, but more stable habitats would make marginal contributions to population dynamics during 'good years', where productivity was maximized at more suitable (but variable) 
habitats. Nonetheless, these sub-populations would play a key role as a valuable population reservoir, able to sustain re-colonization of optimal habitats after catastrophic years.

While our findings are far from conclusive regarding which of the three hypotheses previously discussed explain the relationships between shallow and deep sea urchin patches in southern Chile, they do emphasize the precautionary value of protecting areas where sea urchins form extensive patches over a wide bathymetric gradient in southern Chile. This is a relevant component of an urgently needed management strategy that should be implemented to protect the over-exploited shallow-water sub-populations in the area and allow for their recovery.

\section{ACKNOWLedgments}

We express our gratitude to all the fishermen that helped to select the study sites for the exploratory transects and provided use of their boats and advice regarding the sites where deep population could be observed. Projects FIP 2007-44 and FONDECYT 1100931 contributed partial funding to this research. We are especially grateful to Mr. Marcos Silva, Mr. Javier Cuevas and crew of the L/M Westhoff IV. Three anonymous reviewers contributed to improve this manuscript.

\section{LITERATURE CITED}

Agatsuma Y, A Nataka \& K Matsuyama. 2000. Seasonal foraging activity of the sea urchin Strongylocentrotus nudus on coralline flats in Oshoro Bay in south-western Hokkaido, Japan. Fisheries Science 66(2): 198-203.

Aiken CM. 2008. Barotropic tides of the Chilean Inland Sea and their sensitivity to basin geometry. Journal of Geophysical Research-Oceans 113(C8): 13.

Aitchison J. 1955. On the distribution of a positive random variable having a discrete probability mass at the origin. Journal of the American Statistical Association 50: 901908.

Akaike H. 1974. A new look at the statistical model identification. Automatic Control, IEEE Transactions 19(6): 716-723.

Andrew NL, Y Agastsuma, E Ballesteros, AG Bazhin, EP Creaser, DKA Barnes, LW Botsford, A Bradbury, A Campbell, D Dixon, S Einarsson, PK Gerring, $K$ Herbert, M Hunter, SB Hur, PK Johnson, MA JuinioMeñez, P Kalvass, RJ Miller, CA Moreno, JS Palleiro, D Rivas, SM Robinson, SC Schroeter, RS Steneck, RL Vadas, DA Woodby \& Z Xiaoqi. 2002. Status and management of world sea urchin fisheries. Oceanography and Marine Biology: An Annual Review 40: 343-425.
Arias E, N Barahona, G Jerez \& E Lozada. 1995. Monitoreo del recurso erizo en la X y XI regiones, 1994. Informe Final FIP 93-13: 1-74. <http://www.fip.cl/Archivos/Hitos/ Informes/inffinal\%2093-13.pdf>

Barahona N, JM Orensanz, AM Parma, G Jerez, C Romero, H Miranda, A Zuleta, V Catasti \& P Galvez. 2003. Bases biológicas para la rotación de áreas en el recurso erizo. Proyecto FIP 2000-18: 1-200. <http://www.fip.cl/ Archivos/Hitos/Informes/inffinal\%202000-18.pdf>

Basch L \& MJ Tegner. 2007. Reproductive responses of Purple sea urchin (Strongylocentrotus purpuratus) populations to environmental conditions across a coastal depth gradient. Bulletin of Marine Science 81(2): 255-282.

Bay-Schmith E, C Werlinger \& J Silva. 1981. Ciclo anual de reproducción del recurso erizo Loxechinus albus entre la X y XII Región, 68 pp. Universidad de Concepción, Concepción.

Bückle F, C Guisado, C Cerrano, I Cordova, L Peña \& E Vasquez. 1977. Estudio del crecimiento en cautiverio del erizo Loxechinus albus (Molina) en las costas de Valparaíso y Chiloé, Chile. Anales del Centro Ciencias del Mar y Limnología, Universidad Nacional Autonoma 4(1): 141-152.

Burdett-Coutts V \& A Metaxas. 2004. The effect of the quality of food patches on larval vertical distribution of the sea urchins Lytechinus variegatus (Lamarck) and Strongylocentrotus droebachiensis (Mueller). Journal of Experimental Marine Biology and Ecology 308: 221-236.

Burnham KP \& DR Anderson. 2004. Multimodel inference. Sociological Methods \& Research 33(2): 261-304.

Buschmann AH, JA Vásquez, P Osorio, E Reyes, L Filún, MC Hernández-González \& A Vega. 2004. The effect of water movement, temperature and salinity on abundance and reproductive patterns of Macrocystis spp. (Phaeophyta) at different latitudes in Chile. Marine Biology 145(5): 849-862.

Bustos E \& S Olave. 2001. El cultivo del erizo (Loxechinus albus), 23 pp. Instituto de Fomento Pesquero, Puerto Montt.

Byrne M. 1990. Annual reproductive-cycles of the commercial sea-urchin Paracentrotus lividus from an exposed intertidal and a sheltered subtidal habitat on the West-Coast of Ireland. Marine Biology 104(2): 275-289.

Cáceres M, A Valle-Levinson, C Molinet, M Castillo \& M Bello. 2006. Lateral variability of flow over a sill in a channel of southern Chile. Ocean Dynamics 56(3-4): 352-359.

Cáceres M, A Valle-Levinson \& M Bello. 2008. Residual flow over a bump in Quellón Bay. Revista de Biología Marina y Oceanografía 43(3): 629-639.

Campagna S, J Lambert \& PArchambault. 2005. Abundance et distribution du concombre de mer (Cucumaria frondosa) et prises accidentelles obtenues par dragage entre Matane et Cap-Gaspé (Québec) en 2004, 72 pp. Institut MauriceLamontagne, Direction Régionale des Sciences Pêches et Océans Canada, Rapport Technique Canadien des Sciences Halieutiques et Aquatiques, Quebec. 
Castro LR, MA Cáceres, N Silva, MI Muñoz, R León, MF Landaeta \& S Soto-Mendoza. 2011. Short-term variations in mesozooplankton, ichthyoplankton, and nutrients associated with semi-diurnal tides in a Patagonian Gulf. Continental Shelf Research 31(3-4): 282-292.

Dierssen HM, RC Zimmerman, LA Drake \& DJ Burdige. 2009. Potential export of unattached benthic macroalgae to the deep sea through wind-driven Langmuir circulation. Geophysical Research Letters 36: 1-5.

Fox J \& W Sanford. 2010. Car: Companion to Applied Regression. R package version 2.0-2. <http://CRAN.Rproject.org/package $=$ car $>$

Gage JD \& PA Tyler. 1985. Growth and recruitment of the deep-sea urchin Echinus affinis. Marine Biology 90(1): 4153.

Gianguzza P, F Badalamenti, F Gianguzza, C Bonaviri \& S Riggio. 2009. The operational sex ratio of the sea urchin Paracentrotus lividus populations: the case of the Mediterranean marine protected area of Ustica Island (Tyrrhenian Sea, Italy). Marine Ecology 30(1): 125-132.

Gonor JJ. 1972. Gonad growth in the sea urchin, Strongylocentrotus purpuratus (Stimpson) (Echinodermata: Echinoidea) and the assumptions of gonad index methods. Journal of Experimental Marine Biology and Ecology 10(2): 89-103.

Guisado C. 1995. Estrategias de desarrollo larval y ciclo de vida en dos especies de echinoideos regulares del sur de Chile. Tesis de Magister, Facultad de Ciencias, Universidad Austral de Chile, Valdivia, 89 pp.

Guisado C \& JA Castilla. 1987. Historia de vida, reproducción y avances en el cultivo del erizo comestible chileno Loxechinus albus (Molina, 1782) (Echinoidea: Echinidae). En: Arana P (ed). Manejo y desarrollo pesquero, pp. 5968. Editorial Universitaria, Valparaíso.

Guisado C, E Arias \& E Peréz. 1998. Estudio reproductivo del erizo en las regiones I a VIII. Informe Final. Proyecto FIP-IT/96-44:1-233. <http://www.fip.cl/Archivos/Hitos/ Informes/inffinal\%2096-44.pdf>

Harrold C, K Light \& S Lisin. 1998. Organic enrichment of submarine-canyon and continental-shelf benthic communities by macroalgal drift imported from nearshore kelp forests. Limnology and Oceanography 43(4): 669678.

Hinojosa I, E González, P Ugalde, N Valdivia, E Macaya \& M Thiel. 2007. Distribución y abundancia de macroalgas flotando a la deriva y su fauna peracarida asociada en los canales de la XI región, Chile. Ciencia y Tecnología del Mar 30(2): 37-50.

Hinojosa IA, M Pizarro, M Ramos \& M Thiel. 2010. Spatial and temporal distribution of floating kelp in the channels and fjords of southern Chile. Estuarine, Coastal and Shelf Science 87(3): 367-377.
Inostroza F, H Robotham, R Salas \& R Serey. 1983. Cartas de distribución de los recursos bento-demersales de las aguas interiores de la X, XI y XII región. Zona I, II. III, y IV, 180 pp. Instituto de Fomento Pesquero, Valparaíso.

Keats DW, DH Steele \& GR South. 1984. Depth-dependent reproductive output of the green sea urchin, Strongylocentrotus droebachiensis (O.F. Müller), in relation to the nature and availability of food. Journal of Experimental Marine Biology and Ecology 80(1): 77-91.

Kelly MS, PV Owen \& P Pantazis. 2001. The commercial potential of the common sea urchin Echinus esculentus from the west coast of Scotland. Hydrobiologia 465: 85-94.

Kerr LA, SX Cadrin \& DH Secor. 2010a. The role of spatial dynamics in the stability, resilience, and productivity of an estuarine fish population. Ecological Applications 20(2): 497-507.

Kerr LA, SX Cadrin \& DH Secor. 2010b. Simulation modelling as a tool for examining the consequences of spatial structure and connectivity on local and regional population dynamics. ICES Journal of Marine Science67: 1631-1639.

Kino S \& Y Agatsuma. 2007. Reproduction of sea urchin Loxechinus albus in Chiloé Island, Chile. Fisheries Science 73: 1265-1273.

Kleinbaum DG, LL Kupper, KE Muller \& A Nizam. 1998. Applied regression analysis and other multivariable methods, 798 pp. Thomson Brooks/Cole, Pacific Grove.

Lamare MD, PE Brewin \& MF Barker. 2002. Reproduction of the sea urchin Evechinus chlroticus (Echinodermata: Echinoidea) in a New Zealand fiord. New Zealand Journal of Marine and Freshwater Research 36: 719-732.

Larraín AP. 1975. Los equinoideos regulares fósiles y recientes de Chile. Gayana Zoología 35: 1-188.

Lawrence JM. 2001. Edible sea urchins: Biology and ecology, 419 pp. Elsevier, Tampa.

Lozada E \& H Bustos. 1984. Madurez sexual y fecundidad de Venus antiqua antiqua King \& Broderip 1835 en la bahía de Ancud (Mollusca: Bivalvia: Veneridae). Revista de Biología Marina 20(2): 91-112

MacCall AD. 1990. Dynamic geography of marine fish populations, 153 pp. University of Washington Press, Seattle.

McCullagh P \& JA Nelder. 1989. Generalized linear models, 258 pp. Chapman \& Hall, London.

Molinet C, A Valle-Levinson, CA Moreno, M Cáceres, M Bello \& M Castillo. 2006. Effects of sill processes on the distribution of epineustonic competent larvae in a stratified system of Southern Chile. Marine Ecology Progress Series 324: 95-104.

Molinet C, E Niklitschek, CA Moreno \& A Arevalo. 2008. Vertical distribution of early and competent larvae of Concholepas concholepas in two systems of Chilean inland seas. Marine Biology 153: 779-787. 
Molinet C, CA Moreno, JM Orensanz, A Parma, J Codjambassis, M Díaz, L Flores, M Matamala, V Almanza, J Enríquez, M Neculman \& E Cortez. 2009. Estudio de poblaciones fuente (profundas) y flujo de dispersión larvaria y reclutamiento de erizos en la XI región (Fase I). Proyecto FIP 2007-44: 1-122. <http://www.fip.cl/ Archivos/Hitos/Informes/inffinal\%202007-44.pdf>

Moreno CA \& JP Sutherland. 1982. Physical and biological processes in a Macrocystis pyrifera community near Valdivia, Chile. Oecologia 55: 1-6.

Moreno CA \& R Vega. 1988. Valor científico de las Reservas Marinas Costeras: un ejemplo de estudio ecológico en poblaciones de Loxechinus albus (Molina). Informe UNESCO Ciencias del Mar 47: 124-134.

Moreno CA, N Barahona, C Molinet, JML Orensanz, AM Parma \& A Zuleta. 2006. From crisis to institutional sustainability in the Chilean sea urchin fishery. En: McClanahan T \& JC Castilla (eds). Fisheries management: progress towards sustainability, pp. 43-67. Blackwell Publishing, Monbasa.

Moreno CA, C Molinet, J Codjambassis, M Diaz, P Diaz \& AArevalo. 2011. Bathymetric distribution of the Chilean sea urchin (Loxechinus albus, Molina) in the inner seas of northwest Patagonia: implications for management. Fisheries Research 110: 305-311.

Park M-J \& D-P Wang. 1991. Transient tidal vorticity over a hollow. En: Parker BB (ed). Tidal hydrodynamics, pp. 419434. Wiley, New York.

Pennington JT. 1983. Efficient estimators of abundance, for fish and plankton surveys. Biometrics 39(1): 281-286.

Pérez A, C Boy, E Morriconi \& J Calvo. 2010. Reproductive cycle and reproductive output of the sea urchin Loxechinus albus (Echinodermata: Echinoidea) from Beagle Channel, Tierra del Fuego, Argentina. Polar Biology 33(3): 271-280.

Pulliam HR. 1988. Sources, sinks, and population regulation. American Naturalist 132(5): 652-661.

Quiroz D \& P Duhart. 2006. Geología del área Quellón - Isla San Pedro: Región de Los Lagos, 20 pp. Servicio Nacional de Geología y Minería, Chile, Carta Geológica de Chile, Serie Geología Básica, Santiago.

Rogers-Bennett L, WA Bennett, HC Fastenau \& CM Dewees. 1995. Spatial variation in red sea urchin reproduction and morphology: Implications for harvest refugia. Ecological Applications 5(4): 1171-1180.

Salas-Monreal D \& A Valle-Levinson. 2009. Continuously stratified flow dynamics over a hollow. Journal of Geophysical Research 114: C03021.

Secor DH, LA Kerr \& SX Cadrin. 2009. Connectivity effects on productivity, stability, and persistence in a herring metapopulation model. ICES Journal of Marine Science: Journal du Conseil 66(8): 1726-1732.
Senaratna M, LH Evans, L Southam \& E Tsvetnenko. 2005. Effect of different feed formulations on feed efficiency, gonad yield and gonad quality in the purple sea urchin Heliocidaris erythrogramma. Aquaculture Nutrition 11: 199-207.

Shpigel M, SC McBrideb, S Marcianoa, S Rona \& A BenAmotzc. 2005. Improving gonad colour and somatic index in the European sea urchin Paracentrotus lividus. Aquaculture 245: 101-109.

Silva N, M Calvete \& HA Sievers. 1998. Masas de agua y circulación general para algunos canales Australes entre Puerto Montt y Laguna San Rafael, Chile (CIMAR-Fiordo 1). Ciencia y Tecnología del Mar 21: 17-48.

Valle-Levinson A \& J Blanco. 2004. Observations of wind influence on exchange flows in a strait of the Chilean inland sea. Journal of Marine Research 62(5): 721-741.

Valle-Levinson A, F Jara, C Molinet \& D Soto. 2001. Observations of intratidal variability of flows over a sill/ contraction combination in a Chilean fjord. Journal of Geophysical Research 106(4): 7051-7064.

Vanderklift MA \& GA Kendrick. 2005. Contrasting influence of sea urchins on attached and drift macroalgae. Marine Ecology Progress Series 299: 101-110.

Vásquez J. 2001. Ecology of Loxechinus albus. En: Lawrence JM (ed). Edible sea urchins: Biology and ecology, pp. 161175. Elsevier Science B.V., Tampa.

Vásquez J, JC Castilla \& B Santelices. 1984. Distributional patterns and diets of four species of sea urchins in giant kelp forest (Macrocystis pyrifera) of Puerto Toro, Navarino Island, Chile. Marine Ecology Progress Series 19: 55-63.

Venables WN \& BD Ripley. 2002. Modern applied statistics with S, 495 pp. Springer, New York.

Vetter EW \& PK Dayton. 1998. Macrofaunal communities within and adjacent to a detritus-rich submarine canyon system. Deep Sea Research Part II: Topical Studies in Oceanography 45(1-3): 25-54.

Villouta E, WL Chadderton, CW Pegsley \& CH Hay. 2001. Effects of sea urchin (Evechinus chloroticus) grazing in Dusky Sound, Fiordland, New Zealand. New Zealand Journal of Marine and Freshwater Research 35: 1007-1024.

Wolfinger R \& M O’Connell. 1993. Generalized linear mixed models: a pseudo-likelihood approach. Journal of Statistical Computation and Simulation 4: 233-243.

Zamora S \& W Stotz. 1994. Cultivo masivo en laboratorio de juveniles de erizo Loxechinus albus (Molina, 1872), (Echinodermata: Echinoidea). Investigación Pesquera 38: 37-54.

Zar JH. 1999. Biostatistical analysis, 663 pp. Prentice Hall, Englewood Cliffs.

Received 20 February 2012 and accepted 11 June 2012

Associate Editor: Martin Thiel 